\title{
Antioxidant and Phytochemical Studies of the Rhizome Extracts of Curcuma amada Roxb and Zingiber officinale Rosc
}

\author{
Jayalakshmi B ${ }^{1, *}$, Kavya Yadav P G ${ }^{1}$, Murali $\mathbf{M}^{2}$, Amruthesh K N² \\ ${ }^{1}$ Department of Botany, Maharani's Science College for Women, Mysuru-570 005, Karnataka, India \\ ${ }^{2}$ Applied Plant Pathology Laboratory, Department of Studies in Botany, University of Mysore, Manasagangotri, Mysuru-570 006, \\ Karnataka, India
}

Received May 6, 2021; Revised June 7, 2021; Accepted July 19, 2021

\section{Cite This Paper in the following Citation Styles}

(a): [1] Jayalakshmi B, Kavya Yadav P G, Murali M, Amruthesh KN, "Antioxidant and Phytochemical Studies of the Rhizome Extracts of Curcuma amada Roxb and Zingiber officinale Rosc," Advances in Pharmacology and Pharmacy, Vol. 9, No. 3, pp. 65 - 74, 2021. DOI: 10.13189/app.2021.090304.

(b): Jayalakshmi B, Kavya Yadav P G, Murali M, Amruthesh K N (2021). Antioxidant and Phytochemical Studies of the Rhizome Extracts of Curcuma amada Roxb and Zingiber officinale Rosc. Advances in Pharmacology and Pharmacy, 9(3), 65 - 74. DOI: 10.13189/app.2021.090304.

Copyright $\odot 2021$ by authors, all rights reserved. Authors agree that this article remains permanently open access under the terms of the Creative Commons Attribution License 4.0 International License

Abstract Various reactive species which are either
radicals or non radicals formed during normal metabolic
processes. Oxidative stress has been identified as a major
causative factor in the development and progression of
several life threatening diseases, including
neurodegenerative and cardiovascular disease, Antioxidants play a vital role in preventing or delaying oxidation and scavenging free radicals. Plants have been used as exogenous antioxidants from several years. In this contest, the rhizome extracts of two important medicinal plants Curcuma amada Roxb and Zingiber officinale Rosc were investigated for antioxidant properties and phytochemical constituents. Antioxidant capacity of different solvent extracts of these plants was estimated by scavenging diphenyl picryl hydrazyl (DPPH), nitric oxide (NO) and hydrogen peroxide. The petroleum ether and alcohol extracts of Curcuma amada showed stronger antioxidant activity with $\mathrm{IC}_{50}$ values of $26-30 \mu \mathrm{g} / \mathrm{ml}$ and $25-29 \mu \mathrm{g} / \mathrm{ml}$, respectively in all the methods while methanol extract showed moderate activity, while petroleum ether and ethanol extracts Zingiber officinale reported good scavenging activity in all the three methods with $\mathrm{IC}_{50}$ ranging from $25-30 \mu \mathrm{g} / \mathrm{ml}$ except hydroxyl radical scavenging method. Petroleum ether extracts of both the test plants exhibited good inhibition of free radicals generated by DPPH, hydrogen peroxide and nitric oxide when compared to standard ascorbic acid. The phenolic substances are commonly present in all the studied extracts. Among the two medicinal plants tested, Zingiber officinale has better scavenging activity in all the performed methods followed by Curcuma amada. In the present study, potent antioxidant activity of Zingiber officinale and Curcuma amada extracts leads to scientific validation of these plants. A natural substance which is a part of daily diet and nutritional supplement with antioxidant property constitutes a new source of herbal drug.

Keywords Antioxidants, Free Radicals, Extracts, Solvents, Phytochemicals

\section{Introduction}

Oxygen in ground state is less reactive, but active oxygen species in other forms such as single oxygen, super oxide radical anion, hydrogen peroxide, etc., are greatly toxic and produce oxidative stress in plants [1]. They are continuously produced by a body via enzymatic and non-enzymatic reactions like respiratory chain reaction, phagocytosis and prostaglandin synthesis. 
Oxidative stress due to free radical has been identified a major source for developing to exert a toxic effect in turn to cause various diseases such as neurodegenerative and cardiovascular problems [2]. The free radicals are deactivated by antioxidants. Antioxidants play a vital role in preventing or delaying oxidation, even at relatively small concentration and thus have various physiological roles in plant body [3].

Antioxidants are materials at relatively low concentrations significantly inhibit the role of oxidation at targets. Due to continuous generation of partially reduced form of oxygen by constitutive metabolic pathways, a number of protective antioxidant enzymes such as, superoxide dismutase (SOD), catalase (CAT), glutathione peroxidase (GSHPX), glutathione reductase (GSHRX), glutathione-s-tranferase (GST) and non-enzymatic antioxidants are required to deal with toxic species [4]. The use of synthetic antioxidants such as Butylated hydroxyanisole (BHA) and butylated hydroxytoluene (BHT) has to be thought twice due to its carcinogenicity [5]. Hence, it is better to turn on to natural compounds especially derived from plants and dietary sources that provide a large number of antioxidants [6]. Plants are good source of exogenous antioxidants. About two-thirds of the plant species in the world have medicinal properties, and many of these have excellent antioxidant capacity [7]. Hence antioxidant potential of plants has received a great deal of attention. Moreover, many plants are considered good source of nutrition and hence they are recommended for their therapeutic values [8].

Dietary materials which are antioxidants play an important role in one's overall health. The human body needs more antioxidants than it has the ability to produce, thus a regular supply of antioxidants is necessary for the body in order to protect it against cellular damage caused by oxidative stress. Antioxidants are abundantly found in vegetables, fruits, leaves, oilseeds, cereal crops etc,. [9]. The literature reports the antibacterial and antioxidant activity of various rhizome extracts. In this contest, the rhizome extracts of two important medicinal plants Curcuma amada Roxb and Zingiber officinale Rosc were investigated for antioxidant properties and phytochemical constituents.

Curcuma amada Roxb plant of the family Zingibaraceae is an important spice. It is commonly called Mango ginger. It is also known as amra haridra, amahaldi, taldiha, banahaldi in different regions. Mango ginger is a perennial herb which is morphologically similar to the ginger but with a mango taste. Rhizomes of mango ginger are mainly used for making pickles because of its mango taste. The major constituents found in its rhizomes are curcuminoids, phenolic compounds and essential oils [10].

Curcuma amada Roxb is a perennial, rhizomatous, aromatic herb plant growing around $80 \mathrm{~cm}$ tall and rhizomes are of mild yellow colour. The plants are adapted to growing in areas of seasonal drought in monsoonal forests, in which they prefer a humus-rich, moist but well-drained soil in a shaded position. It is found wild as well as cultivated in various parts of world. In India, the plant is cultivated in tropical areas of Gujarat, West Bengal, Uttar Pradesh, Karnataka, Tamilnadu, Konkan, and in the hills of western coast of India. Mature Mango ginger plants can be harvested after 6 months of germination. Its rhizome used as a mild ginger - flavoured spice in pickle [11]. It has numerous biological activities such as antioxidant, antibacterial, anti- inflammatory, antifungal and analgesic. In Ayurveda and Unani medicine, rhizome of mango ginger is used for treating coughs and other chest complains such as bronchitis and a wide range of digestive problems such as stomach pain, loss of appetite, indigestion, for healing of wounds, cuts itching in skin diseases, asthma and inflammation. Also, it is used as carminative, expectorant, appetizer and laxative [12].

Zingiber officinale Rosc is an important spice of the family Zingibaraceae. It is commonly called ginger. It is cultivated in tropical and subtropical countries of the world, while in India in the states like Kerala, Arunachal Pradesh, Orissa, Meghalaya, West Bengal, Tamil Nadu, Andhra Pradesh and Karnataka which is a rain fed crop propagated by seed tubers and should be harvested from the fifth month after sowing. Ginger is a plant whose rhizome is widely used as a spice for folk medicines and considered a universal medicine by India's ayurvedic herbalists. Its sweet taste has made it a popular herb and used in breads, candies, and tonics. Ginger is known to work as a digestive aid by increasing the production of digestive fluids and saliva, which helps to relieve indigestion, gas pains, diarrhoea and stomach cramping. It is to be strong antioxidant and good antimicrobial agent for sores, wounds and protects the liver and stomach, also useful for bowel disorders, circulatory problems, arthritis, fever, headache, motion sickness, hot flashes, muscle pains, nausea and vomiting [12].

\section{Materials and Methods}

\subsection{Collection and Extraction of Plant Material}

Rhizome of two medicinal plants Curcuma amada and Zingiber officinale were selected for the determination of antioxidant activity. The Curcuma amada and Zingiber officinale rhizome (Figure 1) were collected that were grown in and around Mysuru. The rhizome were washed, cut into small pieces and dried for few days in shade at room temperature. Air dried rhizome were powdered using a warring blender. 


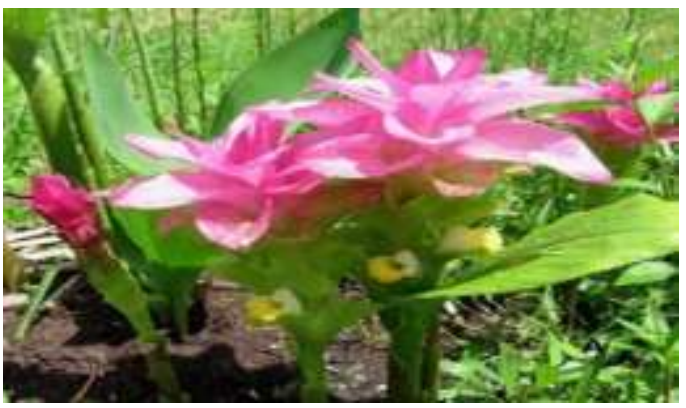

A

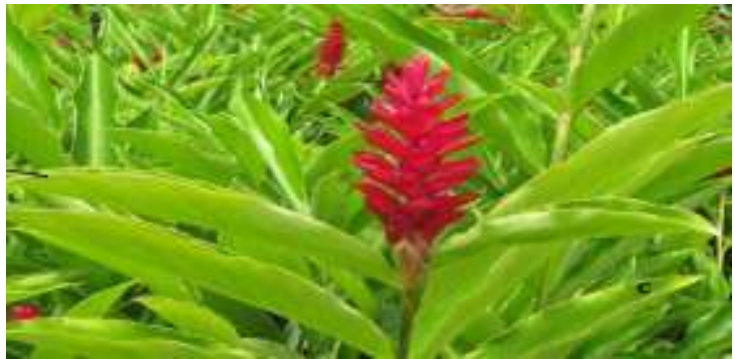

C

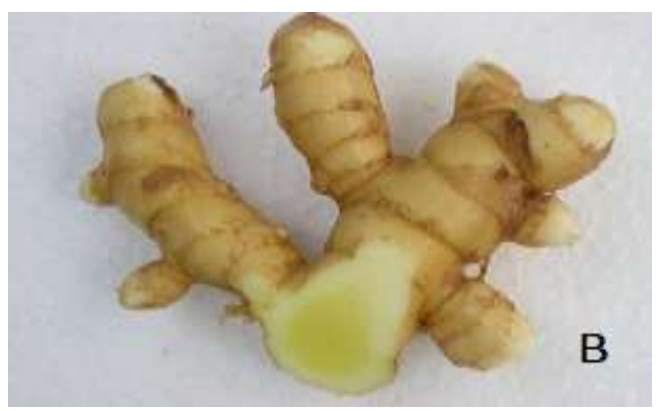

B

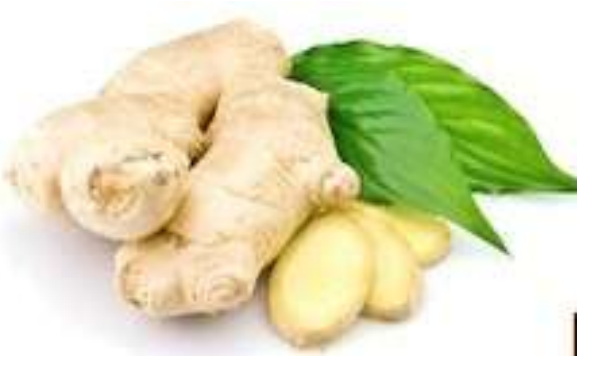

Figure 1. Screened plants for antioxidant activity A - Curcuma amada plant; B - Curcuma amada rhizome; C - Zingiber officinale plant; D - Zingiber officinale rhizome

Solvent extraction was carried out using soxhlet apparatus. Powdered material $(100 \mathrm{mg})$ was placed in a porous thimble in the upper chamber and in the lower boiling flask; the extracting solvent $(200 \mathrm{ml})$ was added. The flask was heated by temperature controlled heating mantle. The round bottom flask was filled with different solvents in the following order petroleum ether, methanol and ethanol based on polarity from low to high. The temperature was set up based on the boiling point of the solvents. The solvent was heated to reflux and extracted. The sample filled in the thimble was extracted till colorless extract was obtained on the top of the extractor. The collected extract was re-concentrated separately for testing by the reduced pressure. After complete evaporation of the solvent, each of the solvent extracts was weighed and preserved in brown air tight bottle.

\subsection{Determination of Antioxidant Activity}

Antioxidant capacity of different extracts of was estimated by scavenging diphenyl picryl hydrazyl (DPPH), nitric oxide (NO) and hydrogen peroxide.

\subsection{DPPH Radical Scavenging Assay}

Free radical- scavenging action of the different extracts was measured in terms of hydrogen donating or radical-scavenging capacity using stable radical DPPH as described by Blois method [13]. The stock solutions were prepared by dissolving $0.001 \mathrm{~g}$ in one $\mathrm{ml}$ of DMSO. Different concentrations i.e., 20, 40, 60, 80 and $100 \mu \mathrm{g}$ of stock solution were made up to $2 \mathrm{ml}$ with methanol.
Methanolic solution of the DPPH $(0.1 \mathrm{mmol})$ was prepared and a volume of $1 \mathrm{ml}$ of the same was added separately to each of above for testing solutions. The mixture of solution and extract was shaken strongly, incubated for $30 \mathrm{~min}$ and then the absorbance was recorded at $517 \mathrm{~nm}$. Each experiment was performed in triplicates and values are reported as the mean \pm Standard Deviation (SD). Ascorbic acid (AA) was used as a standard parallel to the test compound and DMSO served as a negative control. The ability of the extracts to scavenge the DPPH radical was calculated using the following equation:

DPPH scavenging effect $(\%)=\left[\left(\mathrm{A}_{c}-\mathrm{A}_{\mathrm{b}}\right) / \mathrm{A}_{\mathrm{c}} \times 100\right]$

where $A_{c}$ and $A b$ are the absorbance values of the control and test sample.

\subsection{Hydroxyl Radical Scavenging Assay}

Capability of the compounds to effectively scavenge hydrogen peroxide was determined by the method of Ruch et al. [14] and compared with butylated hydroxyanisole (BHA) which is used as a standard. The Fenton system generated hydroxyl radical $\left(\mathrm{OH}^{\circ}\right)$ in aqueous media. The stock solutions were prepared by dissolving $0.001 \mathrm{~g}$ of the extracts in one $\mathrm{ml}$ of DMSO. The assay mixture $(5 \mathrm{ml})$ contained following reagents: safranin $(11.4 \mu \mathrm{mol})$, EDTA-Fe(II) $(40 \mu \mathrm{mol}), \mathrm{H}_{2} \mathrm{O}_{2}(1.76 \mu \mathrm{mol})$, the extract solution $(4,8,12,16$ and $20 \mu \mathrm{l})$ and a phosphate buffer $(0.067 \mathrm{~mol}, \mathrm{pH} 7.4)$. The assay mixtures were incubated at $37^{\circ} \mathrm{C}$ for $30 \mathrm{~min}$ in water. The scavenging effect of the extracts on hydroxyl radicals generated by Fenton's system is quantified spectrophotometrically at $532 \mathrm{~nm}$. Butylated 
hydroxyanisole was used as a standard. Each experiment was done in triplicates and values are reported as the mean \pm standard deviation (SD). The suppression ratio for $\mathrm{OH}^{*}$ was calculated using the following formula:

$$
\text { Suppression ratio }(\%)=\left[\left(\mathrm{A}_{\mathrm{o}}-\mathrm{A}_{\mathrm{i}}\right) / \mathrm{A}_{\mathrm{o}} \times 100\right]
$$

where $A_{0}=$ Absorbance of the control; $A_{\mathrm{i}}=$ Absorbance of the test compound/ extract.

\subsection{Nitric Oxide Scavenging Assay}

Nitric oxide radical scavenging capacity was determined according to the method of Green et al. [15]. Griess reagent was used to quantify the nitrite, which is produced by the nitroprusside at physiological $\mathrm{pH}$. Sodium nitroprusside $10 \mathrm{mM}(1.5 \mathrm{ml})$ in phosphate buffer ( $\mathrm{pH} 7.4)$ was mixed with various concentrations $(20,40$, 60,80 and $100 \mu \mathrm{g}$ ) of $1 \mathrm{ml}$ extract and the mixture was incubated at $25^{\circ} \mathrm{C}$ for $150 \mathrm{~min}$ and sodium nitroprusside spontaneously generates nitric oxide during this duration. After incubation, $1.5 \mathrm{ml}$ Griess reagent $(1 \%$ sulphanilamide, $2 \%$ phosphoric acid and $0.1 \%$ naphthylethylenediamine dihydrochloride) was added and incubated at room temperature for $30 \mathrm{~min}$. The final volume of the test solution was made-up to $4 \mathrm{ml}$ with the phosphate buffer $(\mathrm{pH}$ 7.4). The reduced nitrite ions are quantified by the absorbance of the solution spectrophotometrically at $546 \mathrm{~nm}$ against the blank. Ascorbic acid was used as the standard in this work. Each experiment was done in triplicate and values are reported as the mean \pm Standard Deviation (SD). The scavenging percent was calculated using the following formula:

Nitric oxide scavenging effect $(\%)=\left[\left(A_{c}-A_{t}\right) / A_{c} \times 100\right]$

$$
A_{c}=\text { absorbance of control }
$$

$A_{t}=$ absorbance in presence of the sample of extract

\subsection{Phytochemical Analysis}

Phytochemical analysis of extracts was carried out for the detection of active secondary metabolites or different constituents such as tannins, alkaloids, flavonoids, terpenoids, steroids, carbohydrates, proteins and saponins. The extracts were reconstituted in methanol and $1 \mathrm{ml}$ of each extract was subjected to standard phytochemical analysis according to the procedure described by Harborne [16].

\section{Results}

\subsection{Yield of the Solvent Extract}

Among the solvent extracts, yield was very good and higher in methanol extract $(105.4 \mathrm{~g} / \mathrm{kg}$ and $102.6 \mathrm{~g} / \mathrm{kg}$ ) than ethanol and petroleum ether extracts in both the screened plants (Table 1).
Table 1. Yield of the solvent extracts

\begin{tabular}{|c|c|c|}
\hline Plants & Solvent Extract & Yield per kg \\
\hline & Petroleum ether & $19.8 \mathrm{~g}$ \\
\hline Curcuma amada & Methanol & $105.4 \mathrm{~g}$ \\
\hline & Ethanol & $13.4 \mathrm{~g}$ \\
\hline & Petroleum ether & $16.3 \mathrm{~g}$ \\
\hline Zingiber offcinale & Methanol & $102.6 \mathrm{~g}$ \\
\hline & Ethanol & $12.3 \mathrm{~g}$ \\
\hline
\end{tabular}

\subsection{Antioxidant Activity of Curcuma amada}

Free radical scavenging activity of the extracts was evaluated by hydrogen donating ability using stable radical DPPH. The ability of the extracts to neutralize hydroxyl radical was expressed as $50 \%$ inhibitory concentration $\left(\mathrm{IC}_{50}\right)$ in $\mu \mathrm{g} / \mathrm{ml}$. The alcohol extract of Curcuma amada was most active with $\mathrm{IC}_{50}$ value at $25 \mu \mathrm{g} / \mathrm{ml}$. Petroleum ether and methanol extracts showed good activity with $\mathrm{IC}_{50}$ values at $30 \mu \mathrm{g} / \mathrm{ml}$ and $29 \mu \mathrm{g} / \mathrm{ml}$, respectively. So, all the extracts showed higher radical scavenging activity compared to standard ascorbic acid $(33 \mu \mathrm{g} / \mathrm{ml})$. In hydroxyl radical scavenging assay, hydroxyl radical generated through Fenton system in aqueous media was inhibited by the scavenging activity of the extract which is expressed as $\mathrm{IC}_{50}$ values and compared with the standard ascorbic acid. The antioxidant activity of Curcuma amada was more potent in petroleum ether extract with $\mathrm{IC}_{50}$ values $27 \mu \mathrm{g} / \mathrm{ml}$ followed by alcohol extract at $31 \mu \mathrm{g} / \mathrm{ml}$ and methanol extract at $35 \mu \mathrm{g} / \mathrm{ml}$. So all the extracts showed good antioxidant activity compared to standard ascorbic activity $(32 \mu \mathrm{g} / \mathrm{ml})$ except methanol extract. The formation of nitrite by the reaction of sodium nitroprusside with oxygen is inhibited by scavenging activity of the extract which is expressed as $\mathrm{IC}_{50}$ values and compared with standard ascorbic acid. The petroleum ether and alcohol extracts showed stronger antioxidant activity with $\mathrm{IC}_{50}$ values at $26 \mu \mathrm{g} / \mathrm{ml}$ and $29 \mu \mathrm{g} / \mathrm{ml}$ respectively and methanol extract showed moderate activity with $\mathrm{IC}_{50}$ value at $31 \mu \mathrm{g} / \mathrm{ml}$. Hence, lower the $\mathrm{IC}_{50}$ value higher will be the scavenging activity (Table 2).

Table 2. The $\mathrm{IC}_{50}$ values of DPPH, Hydrogen peroxide and Nitric oxide radical scavenging by different extracts of Curcuma amada

\begin{tabular}{|c|c|c|c|}
\hline \multirow{2}{*}{ Solvent extracts } & \multicolumn{3}{|c|}{ IC $_{\mathbf{5 0}}(\boldsymbol{\mu g} / \mathbf{m l})$} \\
\cline { 2 - 4 } & $\mathbf{D P P H}$ & $\mathbf{H}_{\mathbf{2}} \mathbf{O}_{\mathbf{2}}$ & Nitric oxide \\
\hline Petroleum ether & $30 \pm 0.65$ & $27 \pm 0.56$ & $26 \pm 0.97$ \\
\hline Methanol & $29 \pm 0.58$ & $35 \pm 0.62$ & $31 \pm 0.53$ \\
\hline Ethanol & $25 \pm 0.35$ & $31 \pm 0.47$ & $29 \pm 0.83$ \\
\hline Ascorbic acid & $33 \pm 0.53$ & $32 \pm 0.98$ & $34 \pm 0.61$ \\
\hline
\end{tabular}

The antioxidant effects of Curcuma amada by DPPH, hydrogen peroxide and nitric oxide radical scavenging methods increases with increase in concentration and the data are depicted in Figures.2, 3 and 4, respectively. 


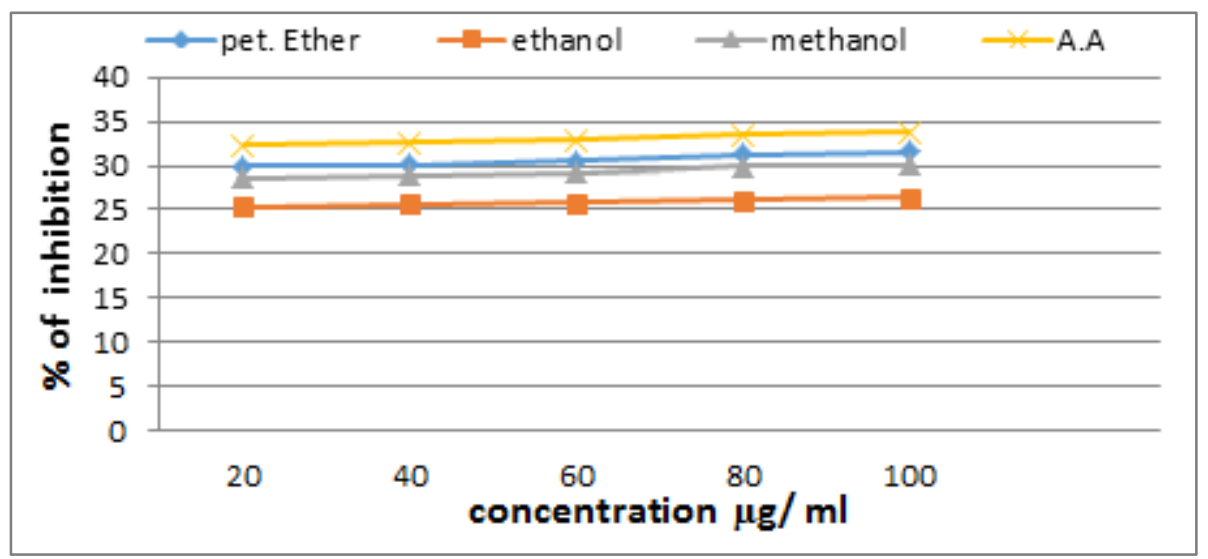

Figure 2. DPPH free radical scavenging activity of different extracts of C. amada and standard ascorbic acid at different concentrations (20-100 $\mu \mathrm{g} / \mathrm{ml})$

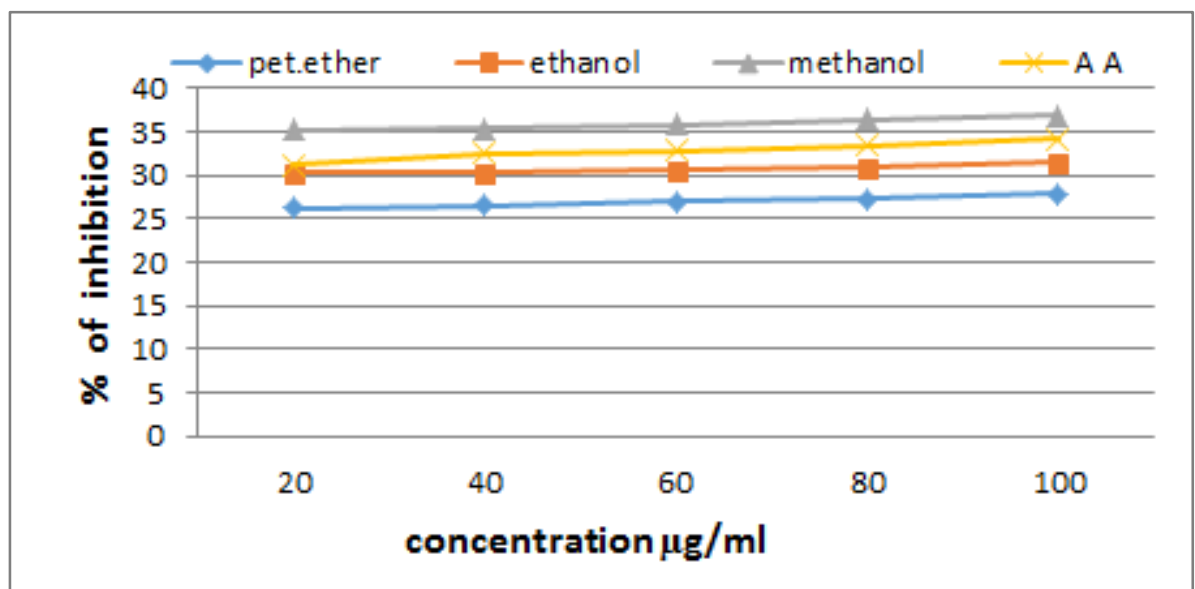

Figure 3. Hydroxyl radical scavenging activity of different extracts of C. amada and standard ascorbic acid at different concentrations $(20-100 \mu \mathrm{g} / \mathrm{ml})$

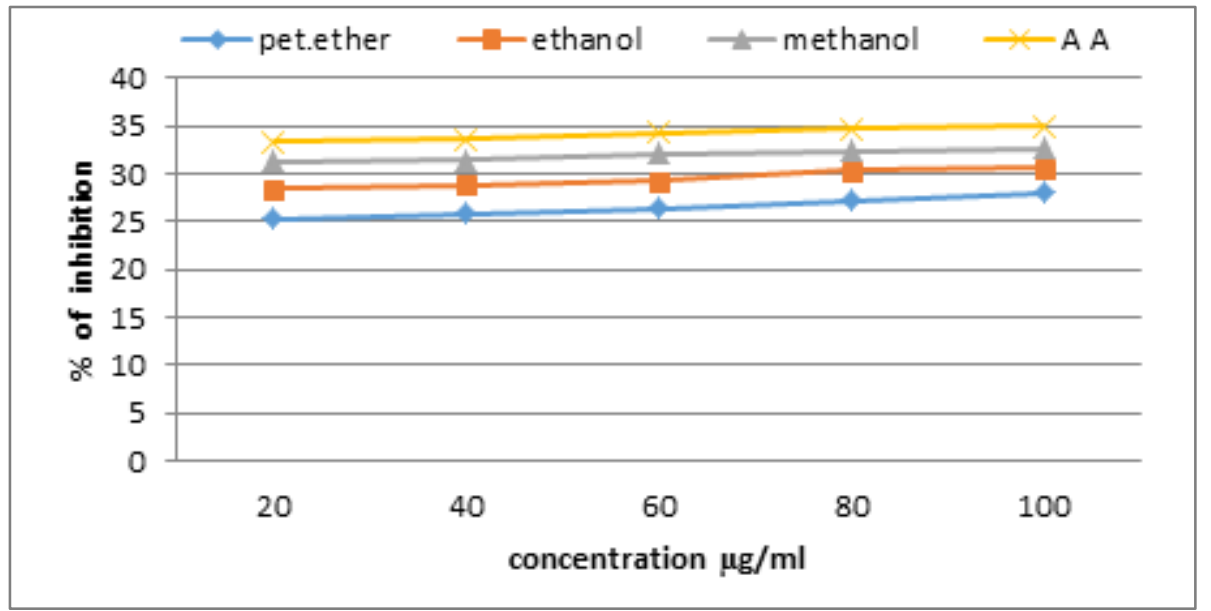

Figure 4. Scavenging effect of nitric oxide radical of different extracts of $C$. amada and standard ascorbic acid at different concentrations $(20-100 \mu \mathrm{g} / \mathrm{ml})$

\subsection{Antioxidant Activity of Zingiber officinale}

Results of DPPH radical scavenging assay of $Z$. officinale showed that all the solvent extracts have higher scavenging efficiency in the order petroleum ether $(24 \mu \mathrm{g} / \mathrm{ml})>$ methanol $(26 \mu \mathrm{g} / \mathrm{ml})>$ alcohol $(30 \mu \mathrm{g} / \mathrm{ml})$ indicating higher activity compared to standard ascorbic acid $(33 \mu \mathrm{g} / \mathrm{ml})$. Results of hydroxyl scavenging assay of $Z$. officinale showed that petroleum ether was most active with the $\mathrm{IC}_{50}$ value of $25 \mu \mathrm{g} / \mathrm{ml}$ while alcohol extract showed moderate scavenging activity at $30 \mu \mathrm{g} / \mathrm{ml}$, but methanol extract showed least activity at $39 \mu \mathrm{g} / \mathrm{ml}$ which is less than that of standard ascorbic acid $(32 \mu \mathrm{g} / \mathrm{ml})$. So, all the plant extracts except methanol have better 
scavenging activity compared to ascorbic acid. The nitric oxide scavenging efficiency was strongest only in petroleum ether extract with $\mathrm{IC}_{50}$ value $23 \mu \mathrm{g} / \mathrm{ml}$, both alcohol and methanol extracts showed good scavenging activity at $25 \mu \mathrm{g} / \mathrm{ml}$ and $26 \mu \mathrm{g} / \mathrm{ml}$, respectively as compared to standard ascorbic acid $(34 \mu \mathrm{g} / \mathrm{ml})$ (Table 3).

The antioxidant activity of Zingiber oficinale by DPPH, hydrogen peroxide and nitric oxide radical scavenging methods increases with increase in concentration and the data are depicted in Figures 5, 6 and 7, respectively.

Table 3. $\mathrm{IC}_{50}$ values of DPPH, Hydrogen peroxide and Nitric oxide radical scavenging by different extracts of Zingiber officinale

\begin{tabular}{|c|c|c|c|}
\hline \multirow{2}{*}{ Solvent extracts } & \multicolumn{3}{|c|}{$\mathrm{IC}_{50}(\mu \mathrm{g} / \mathrm{ml})$} \\
\cline { 2 - 4 } & $\mathrm{DPPH}$ & $\mathrm{H}_{2} \mathrm{O}_{2}$ & Nitric oxide \\
\hline Petroleum ether & $24 \pm 0.94$ & $25 \pm 0.99$ & $23 \pm 0.65$ \\
\hline Methanol & $26 \pm 0.85$ & $39 \pm 0.71$ & $26 \pm 0.68$ \\
\hline Ethanol & $30 \pm 0.73$ & $30 \pm 0.49$ & $25 \pm 0.53$ \\
\hline Ascorbic acid & $33 \pm 0.53$ & $32 \pm 0.98$ & $34 \pm 0.61$ \\
\hline
\end{tabular}

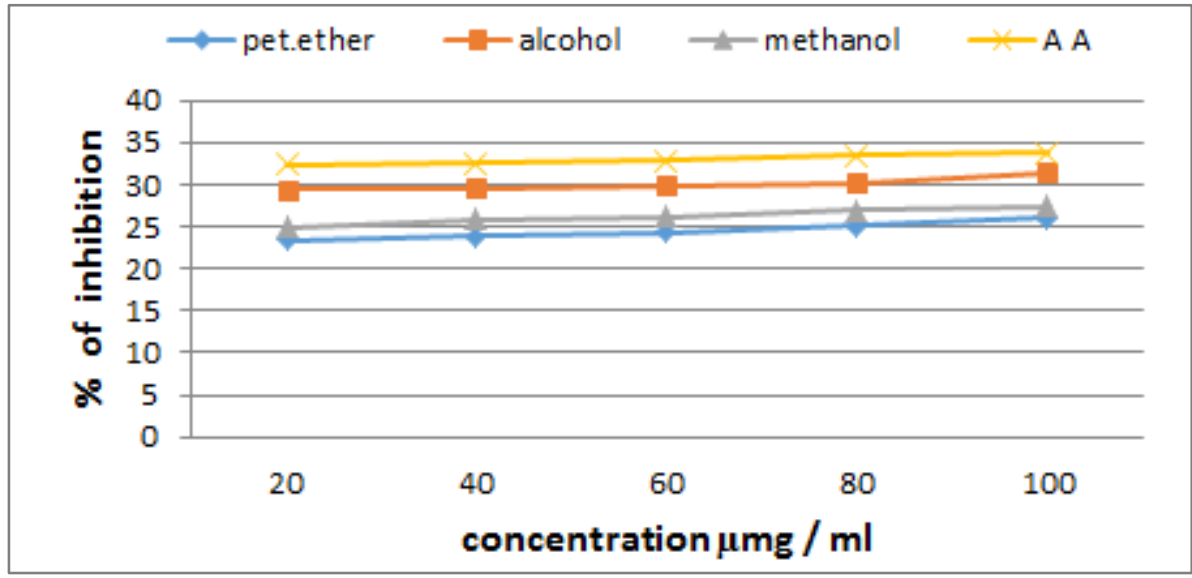

Figure 5. DPPH free radical scavenging activity of different extracts of $Z$. officinale and standard ascorbic acid at different concentrations $(20-100 \mu \mathrm{g} / \mathrm{ml})$

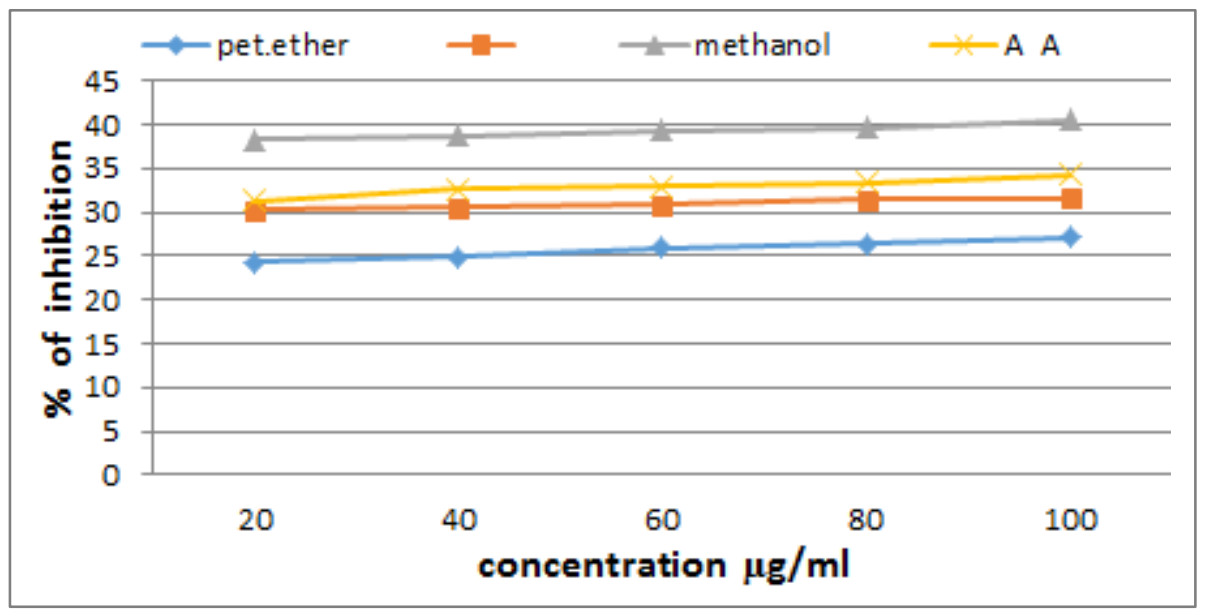

Figure 6. Hydroxyl radical scavenging activity of different extracts of $Z$. officinale and standard ascorbic acid at different concentrations $(20-100 \mu \mathrm{g} / \mathrm{ml})$ 


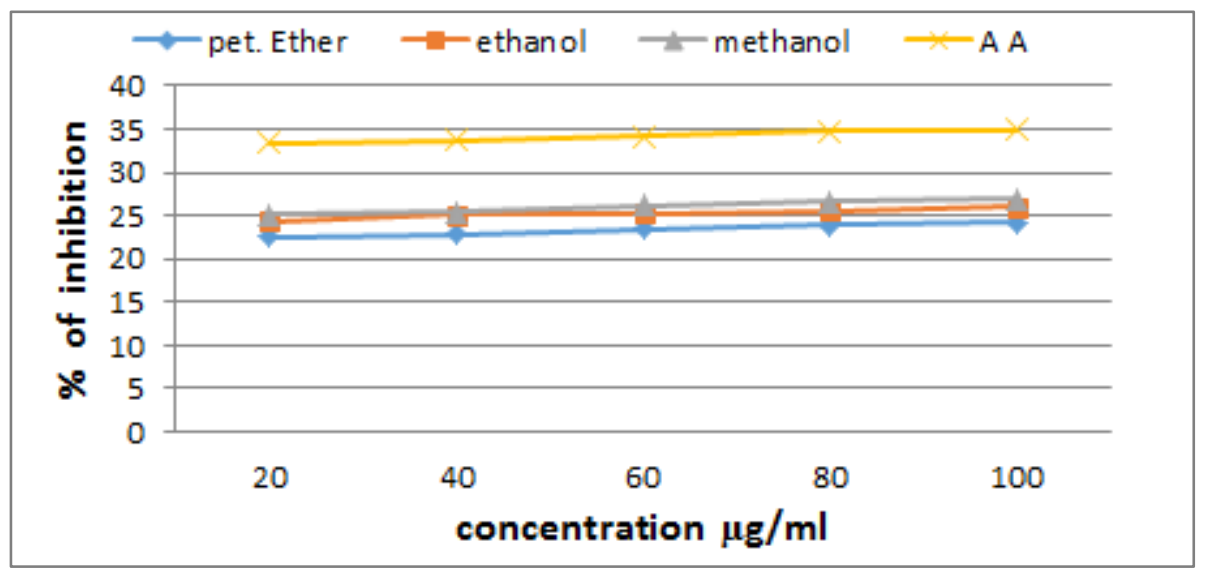

Figure 7. Scavenging effect of nitric oxide radical of different extracts of $Z$. officinale and standard ascorbic acid at different concentrations $(20-100 \mu \mathrm{g} / \mathrm{ml})$

\subsection{Phytochemical Analysis of Solvent Extracts of Curcuma amada and Zingiber officinale}

The petroleum ether extract of Curcuma amada showed presence of flavonoids, tannins and proteins, Ethanol extract showed presence of terpenoids, tannins, carbohydrates, saponins and methanol extract showed presence of terpenoids, tannins, carbohydrates and flavonoids (Table 4).

Table 4. Phytochemical composition of solvent extracts of Curcuma amada

\begin{tabular}{|c|c|c|c|}
\hline \multirow{2}{*}{$\begin{array}{c}\text { Phytochemical } \\
\text { compounds }\end{array}$} & $\begin{array}{c}|c| \\
\text { Petroleum } \\
\text { ether }\end{array}$ & Methanol & Ethanol \\
\hline Flavonoids & + & + & - \\
\hline Terpenoids & - & + & + \\
\hline Tannins & + & + & + \\
\hline Steroids & - & - & - \\
\hline Carbohydrates & - & + & + \\
\hline Proteins & + & - & - \\
\hline Saponins & - & - & + \\
\hline
\end{tabular}

Table 5. Phytochemical composition of solvent extracts of Zingiber oficinale

\begin{tabular}{|c|c|c|c|}
\hline \multirow{2}{*}{$\begin{array}{c}\text { Phytochemical } \\
\text { compounds }\end{array}$} & \multicolumn{3}{|c|}{ Extracts } \\
\cline { 2 - 4 } & PE & Methanol & Ethanol \\
\hline Flavonoids & + & + & + \\
\hline Terpenoids & - & + & + \\
\hline Tannins & + & + & + \\
\hline Steroids & - & - & - \\
\hline Carbohydrates & - & + & + \\
\hline Proteins & + & + & + \\
\hline Saponins & + & + & + \\
\hline
\end{tabular}

Petroleum ether extract of Zingiber oficinale showed presence of tannins, proteins and saponins, ethanol showed presence of flavonoids, terpenoids, tannins, proteins and saponins and methanol extracts showed the presence of flavonoids, terpenoids, tannins, carbohydrates, saponins and proteins (Table 5).

\section{Discussion}

Free radicals produced in body as fragments that are containing a number of unpaired electrons in its outermost molecular or atomic orbitals [17]. These free radicals damage the body cells and disrupt the body metabolism and cause health problems such as cardiac diseases, cancer etc. Hence, these free radicals can be inhibited by the use of antioxidants. This antioxidant neutralizes free radicals and protects the body from cell damage. These antioxidants are present in a number of green leafy vegetables, citrus fruits, etc. The antioxidant activity can be recorded by free radical scavenging capacity, inhibition of lipid peroxidation, metal ion chelating ability and reducing ability.

DPPH, hydroxyl radical and nitric oxide scavenging methods are selected for the determination of antioxidant activity in the current study. The scavenging ability of the samples is the measure of antioxidant activity. In DPPH method, a stable radical is used as a substrate to evaluate the antioxidant activity of Curcuma amada and Zingiber officinale extracts. The hydrogen donating ability is responsible for the effect of antioxidants by DPPH radical scavenging. Hence, the DPPH scavenging activities of the extracts were taken as parameter to check their antioxidant potential. The petroleum ether, methanol and ethyl alcohol extracts of Curcuma amada have good scavenging activity with $\mathrm{IC}_{50}$ values ranging from $25-30 \mu \mathrm{g} / \mathrm{ml}$ which is lesser than the standard ascorbic acid $(33 \mu \mathrm{g} / \mathrm{ml})$. All the extracts of Zingiber officinale have good scavenging activity at concentrations lower than that of standard.

Hydroxyl radicals are the most reactive reduced form of dioxygen that are known to initiate cell damage [18]. The 
petroleum ether $(27 \mu \mathrm{g} / \mathrm{ml})$ and ethyl alcohol $(31 \mu \mathrm{g} / \mathrm{ml})$ extracts have showed good scavenging activity compared to standard ascorbic acid $(32 \mu \mathrm{g} / \mathrm{ml})$. Petroleum ether extract of $Z$. officinale have exhibited very good scavenging activity.

Nitric oxide radical scavenging activity was determined by the ability of the extract to inhibit the formation of nitric oxide ions that can be produced by the interaction of nitric oxide generated by sodium nitroprusside in aqueous solution at physiologically $\mathrm{pH}$ [19]. Petroleum ether, methanol and ethyl alcohol extracts of Curcuma amada have exhibited good scavenging activity with $\mathrm{IC}_{50}$ values ranging from $26-31 \mu \mathrm{g} / \mathrm{ml}$ lesser than that of ascorbic acid $(33 \mu \mathrm{g} / \mathrm{ml})$. Also, all solvent extracts of $Z$. officinale showed good scavenging activity with least $\mathrm{I}_{\mathrm{C} 50}$ values ranging from $23-26 \mu \mathrm{g} / \mathrm{ml}$.

Petroleum ether extracts of both the test plants exhibited good inhibition of free radicals generated by DPPH, hydrogen peroxide and nitric oxide when compared to standard ascorbic acid. Methanol and ethanol extracts of all the plants exhibited moderate and good scavenging activity.

The study of antioxidant activity of Curcuma amada was done by earlier workers with various solvent extracts mainly methanol and ethanol extracts $[20,21,22]$. In the present study antioxidant activity of extracts of petroleum ether also proved to have good scavenging activity which has not been reported in literature. This indicates that even petroleum ether along with other solvents like methanol, ethanol, acetone, ethyl acetate and chloroform also have potent radical scavenging capacity $[9,23]$.

Antioxidant activity of Zingiber officinale showed that petroleum ether and ethanol extracts have good scavenging activity in all these three methods with $\mathrm{IC}_{50}$ ranging from $25-30 \mu \mathrm{g} / \mathrm{ml}$ except hydroxyl radical scavenging method. The literature reports antioxidant activity done by DPPH, ABTS, AFCA and FRAP methods $[24,25]$ but in the present work in all three DPPH, hydroxyl radical and nitric oxide scavenging methods showed good antioxidant activity which confirms the free radical scavenging ability of Zingiber officinale. In literature there are some reports of antioxidant activity using solvent extracts of hexane, acetone, methanol, ethyl acetate and ethanol $[26,27,28]$. In the present study the solvents like petroleum ether, methanol and ethanol were used and all of them have showed good results. The literature study reported methanol and ethanol extracts as potent radical scavengers $[26,24,29]$ but the present study reports petroleum ether extract also showed good scavenging capacity, which confirms it also a potent extract for scavenging. The rhizome of $Z$. officinale have good scavenging capacity and it can be used for potential applications as antioxidants in food systems and various solvent extracts played an important role in the modulation of oxidative stress [30].

The phytochemical analysis of all the solvent extracts of Curcuma amada and Zingiber officinale rhizomes flavonoids were commonly present in all the studied extracts. Terpenoid present in all the solvent extracts except petroleum ether extract of $C$. amada and $Z$. officinale. Tannins were present in all the extracts of $C$. amada and Z. officinale. Saponins were present only in alcohol extract of $\mathrm{C}$. amada and petroleum ether, methanol and ethanol extracts of $Z$. officinale. So it was observed that maximum phytochemicals were present in $Z$. officinale.

The phenolic substances are commonly present in all the studied extracts [31]. The scavenging activities of phenolic substances may be due to active hydrogen donating ability of hydroxyl substituent, since phenolic compounds present in the extract are good electron donors and may contribute to the conversion of hydrogen peroxide to water. The correlation between phenol content and antioxidant activity can be influenced by extraction procedure assay methods, solvents and variation in the nature of compounds responsible for antioxidant activity [32]. Hence, among the two medicinal plants tested, Zingiber officinale has better scavenging activity in all the performed methods followed by Curcuma amada.

There are several methods followed for the determination of antioxidant activity. The chemical complexity of extracts which is a mixture of group of compounds with different functional groups, polarity and chemical behavior may lead to scattered results depending on the method employed [33]. Therefore, an approach with multiple assays for evaluating the antioxidant potential is appropriate.

\section{Conclusions}

The antioxidants efficacies of the plant materials have remarkable properties as therapeutic agents in combating various diseases caused by oxidative stress. The chemical constituents present in the herbal medicine or plants are a part of the physiological functions and hence are thought to have better compatibility with human body. Hence, the use of natural antioxidants mainly from medicinal plants rich in phenolic compound has to be encouraged and validated with scientific experimental investigations. In conclusion, in the present study potent antioxidant activity of Zingiber officinale and Curcuma amada extracts leads to scientific validation of these plants. A natural substance which is a part of daily diet and nutritional supplement with antioxidant property constitutes a new source of herbal drug.

\section{Acknowledgements}

The authors are thankful to the Post-graduate Department of Botany, Maharanis Science College 
Mysuru, Department of Collegiate Education, Govt. of Karnataka, Bengaluru and also the Department of Studies in Chemistry, University of Mysore, Mysuru for providing the laboratory facilities.

\section{REFERENCES}

[1] Antal, DS., "Medicinal plants with antioxidant properties from Banat region (Romania): a rich pool for the discovery of multi-target phytochemicals active in free-radical related disorders". Analele Universitatii din Oradea - Fascicula Biologie Tom. XVII/1, 14-22, 2010.

[2] Halliwell B. and Gutteridge JMC., Reactive species can be poisonous, in Free Radicals in Biology and Medicine. $4^{\text {th }}$ ed. Oxford University Press Inc., New York, USA. 2007.

[3] Sardarodiyan M. and Mohamadi Sani A., Natural antioxidants: sources, extraction and application in food systems. Nutrition \& Food Science, 46, 3, 363-373, 2016.

[4] Bahare Salehi, Miquel Martorell, Jack L. Arbiser, Antoni Sureda, Natália Martins, Pawan Kumar Maurya, Mehdi Sharifi-Rad, Pradeep Kumar and Javad Sharifi-Rad Antioxidants: Positive or Negative Actors? Biomolecules 8, 124,2018

[5] Botterweck AAM., Verhagen H., Goldbohm RA., Kleinjans J. and Van Den B, PA. Intake of butylated hydroxyanisole and butylated hydroxytoluene and stomach cancer risk: Results from analyses in the Netherlands Cohort Study. Food and Chemistry Toxicology 38, 599-605. 2000.

[6] Pokorny J. Are natural antioxidants better- and safer- than synthetic antioxidants. European Journal of Lipid Science and Technology 109, 629-642, 2007.

[7] Cowan MM. Plant products as antimicrobial agents. Clinical Microbiology Reviews 12,4-582, 1999.

[8] Ndiamaka O H., Chika J Mbah, IfeomaOrabueze., Antioxidants Properties of Natural and Synthetic Chemical Compounds: Therapeutic Effects on Biological System. Acta Scientific Pharmaceutical Sciences 3,6, 28-42, 2019.

[9] Kumar M T, Mary VCA, Anusha M, Malaiswamy A, Shivaraj C, Arjun P, Raaman N, Anticancer and antioxidant activity of Curcuma zedoaria and Curcuma amada rhizome extracts. Journal Academic Industrial Research, 1, 2, 91-96, 2012.

[10] Shan B., Cai YZ., Sun M., Corke H., Antioxidant capacity of 26 spice extracts and characterization of their phenolic constituents. Journal Agricultural Food Chemistry. 53, $7749-7759,2005$.

[11] Vaidya ADB. and Devasagayam TPA., Current status of herbal drugs in India: An overview. Journal of Clinical Biochemistry and Nutrition 41,1-11, 2007.

[12] Udayan and Balachandran I. Medicinal plants of Arya Vaidya Sala Herbal Garden, Araya Vaidya Sala, Kottakkal. pp. 522., 2009.

[13] Blois M S., Antioxidant determinations by the use of a stable free radical. Nature, 181, 1199-1200, 1958.
[14] Ruch R.J., Cheng S.J. and Klaunig J.E.. Prevention of cytotoxicity and inhibition of intercellular communication by antioxidant catechins isolated from Chinese green tea. Carcinogenesis 10, 1003-1008, 1989.

[15] Green LC., Wagner, DA., Glogowski, J., Skipper, PL., Wishnok, J.K. and Tannenbaum, S. R.. Analysis of nitrate, nitrite and $\left[{ }^{15} \mathrm{~N}\right]$ nitrate in biological fluids. Analytical Biochemistry 126,131-138, 1982.

[16] Harborne JB. 1998. Phytochemical Methods, Chapman and Hall Publications, London, pp. 7-8.

[17] Sen S., Chakraborty R., Sridhar C., Reddy YSR. and De B., Free radicals, antioxidants, diseases and phytomedicines: current status and future prospect. International Journal of Pharmaceutical Sciences Review and Research, 3,1, 91-100, 2010.

[18] Labelle E., Grange MJC., Elbim C., Marquetty MA., Pacidalo G. and Pasquier C., Hydroxyl radical as a potential intracellular mediator of polymorphonuclear neutrophil apoptosis. Free radical Biology and medicine 24,563-572, 1998.

[19] Bunaciu AA., Aboul-Enein HY. and Fleschin S., FTIR spectrophotometric methods used for antioxidant activity assay in medicinal plants. Applied Spectroscopy Reviews, 47,4, 245-255, 2012

[20] Joshi and Chouhan RS.,. Evaluated the phytochemical analysis and cytotoxicity studies of Curcuma amada rhizomes. International journal of scientific research in Environmental Sciences 1, 12, 365-371,2011.

[21] Gupta K, Himanshu G and Panday A. Evaluation of Antioxidant potential of different extracts of mango ginger rhizome.. International journal of pharmaceutical sciences and research. 6,9, 3986- 3989, 2015

[22] Policegoudra RS., Rehna K., Rao LJ. and Aradhya S.M. Antimicrobial, antioxidant, cytotoxicity and platelet aggregation inhibitory activity of a novel Molecule isolated and characterized of mango ginger(Curcuma amada Roxb.) rhizome. Journal of Bioscienc. 35, 231-240. 2010

[23] Sriramulu H and Donipati S., In vitro bio- evaluation and correlation of antioxidant activity of different extracts of Curcuma amada. Journal of Pharmaceutical, chemical and Biological Sciences. 3,3, 373-377, 2013.

[24] Morakinya AO., Oludare GO., Aderinto OT. and Tasdup A,). Evaluated the antioxidant and free radical scavenging activities of aqueous and ethanolic extracts of Zingiber officinale. Biology and Medicine. 35, 25-30, 2011.

[25] Vishnupriya M., Nishana S., Shashikumar JM., Priya darshini D., Gopalakrishnan V. K., Evaluated the chemical composition and antioxidant activity of essential iol from curcuma amada. International Research Journal of Pharmacy. 3,6,9-103, 2012.

[26] Adel P and Prakash J. Evaluation of the chemical composition and antioxidant activity of Ginger root. Journal of Medicinal Plant Research 4,24, 2674-2679, 2010.

[27] Offei- okyne R., Patterson J., Walker LT., and Martha verghese. Evaluated processing effects on phytochemical content and antioxidant potential of Zingiber officinale. Food and Nutrition Sciences 6, 445-451, 2012. 
[28] Badreldin HA, Blunden G, Tanira MO, Nemmar A, Some phytochemical, pharmacological and toxicological properties of ginger (Zingiber officinale Roscoe): A review of recent research. Food and Chemical Toxicology, 46, 409-420,2008

[29] Ghasemzadeh Hawa ZE. Jaafar and Asmah rahmat. Evaluation of antioxidant activities, total phenolics and flavonoids content in two varieties of Malaysian young ginger. Molecules 15, 4324-4333, 2010.

[30] Mandal S, Yadav S., and Nema RK., Antioxidants: A review. Journal of Pharmaceutical and clinical Research 4,
54-58, 2009.

[31] Sadhana G and Gupta A K, Evaluation of phenolics content, flavonoids and antioxidant activity of Curcuma amada and Zingiber officinale, Journal of Chemistry.1:32-35, 2013.

[32] Mathew and Abraham,. In vitro antioxidant and scavenging effects of Cinnamomum verum leaf extract assayed by different methodologies, Food and Chemical Technology 44: 198-206, 2006.

[33] Karadag A., Ozcelik B. and Saner S. Review of methods to determine antioxidant capacities. Food Analytical Methods 2: 41-60, 2009. 